\title{
Proliferative renal myxosporidiosis in spawning coho salmon (Oncorhynchus kisutch) in British Columbia and Washington
}

\author{
Simon Jones ${ }^{1}$, Gina Prosperi-Porta ${ }^{1}$, Sheila Dawe ${ }^{1}$, Janice Blackbourn ${ }^{1}$, Kimberley Taylor $^{1}$, Geoffrey Lowe $^{1}$ \\ and Andrea Osborn ${ }^{2}$
}

\author{
${ }^{1}$ Department of Fisheries and Oceans, Pacific Biological Station, 3190 Hammond Bay Road, Nanaimo, British Columbia, \\ V9T 6N7, Canada; \\ ${ }^{2}$ Seahorse Veterinary Service, 2650 Randle Road, Nanaimo, British Columbia, V9S 3X2, Canada
}

Key words: Oncorhynchus kisutch, kidney, extrasporogonic myxosporean, senescence

\begin{abstract}
An unidentified myxosporean parasite (CKX) is described from the kidney of approximately $80 \%$ of spawning coho salmon Oncorhynchus kisutch (Walbaum) in British Columbia, Canada and Washington, United States of America. Morphological features were described using light and electron microscopy. Sequencing of polymerase chain reaction (PCR) amplified 18S ribosomal RNA gene and in situ hybridisation were used to further characterise CKX. The parasite occurred with a focal distribution within tubule epithelial cells, the tubule lumen and the interstitium as primary cells containing from one to at least 16 secondary cells. Luminal stages were degenerate and sporogony was not observed. In situ hybridisation using a digoxygenin-labelled DNA probe confirmed CKX to be the source of DNA used in PCR analyses. CKX 18S rDNA sequences were most similar (97\%) to those of Sphaerospora oncorhynchi. Phylogenetic analysis revealed similarities among the $18 \mathrm{~S}$ rDNA sequences of CKX, S. oncorhynchi and Myxidium lieberkuehni. CKX is hypothesised to be the abortive extrasporogonic development of a Sphaerospora sp. or Myxidium sp. occurring in immune-incompetent spawning and senescent salmon.
\end{abstract}

Elevated pre-spawn mortality was observed among returning stocks of adult coho salmon Oncorhynchus kisutch (Walbaum) migrating in streams along northern Vancouver Island. Analysis of specimens from the initial diagnostic case indicated that the furunculosis bacterium Aeromonas salmonicida contributed to the mortality. Routine histological examination of kidney from moribund and fresh-dead salmon also revealed foci of infection with intracellular parasites that resembled extrasporogonic myxosporean stages. This pattern of infection had not previously been noted in coho salmon. The present study describes the parasite in coho salmon, herein referred to as the unknown coho kidney parasite $(\mathrm{CKX})$, and reports on its occurrence in Canada and the United States.

\section{MATERIALS AND METHODS}

Coho salmon locations and samples. Samples of posterior kidney, liver, spleen and gill were collected from fresh spawned salmon belonging to Marble, Cluxewe, Washlawis, Waukwaas, Quatse and Stephens Rivers stocks in northern Vancouver Island, British Columbia, Canada. All dissecting tools were carefully cleaned between fish by rinsing first with water, then bleach, then water, then $95 \%$ ethanol followed by flaming. From each organ sample, small $\left(1-2 \mathrm{~mm}^{3}\right)$ pieces were preserved in $2 \%$ glutaraldehyde in $0.1 \mathrm{M}$ Sörensen's phosphate buffer $(\mathrm{pH} 7.2)$ and two larger $\left(10-20 \mathrm{~mm}^{3}\right)$ pieces were fixed in $95 \%$ ethanol and Davidson's solution, respectively. Similarly, duplicated $10-20 \mathrm{~mm}^{3}$ kidney samples collected from the Quinault, Sooes, Methow and Wenatchee
Rivers, Washington, United States of America were fixed in Davidson's solution and 95\% ethanol, respectively.

Histological analysis. Tissues preserved in Davidson's solution were dehydrated through isopropanol, cleared in xylene and embedded in paraffin wax. Sections $(5 \mu \mathrm{m})$ were mounted on glass slides and stained with haematoxylin and eosin, modified Pappenheim (Humason 1972), Gram or periodic acid Schiff (PAS) stains. Tissues fixed in ethanol were processed as described above and sections $(5 \mu \mathrm{m})$ were mounted onto aminoalkylsilane (AAS) treated slides for in situ hybridisation (ISH). Control tissues for ISH (Atlantic salmon skeletal muscle infected with Kudoa thyrsites, sockeye salmon kidney infected with Parvicapsula minibicornis) were fixed in $95 \%$ ethanol and processed as described above.

Transmission electron microscopy (TEM). Glutaraldehyde-preserved kidney was rinsed twice in Sörensen's buffer and post-fixed in cold $\left(4^{\circ} \mathrm{C}\right) 1 \%$ osmium tetroxide for $1.5 \mathrm{~h}$. The tissue was rinsed, dehydrated through ethanol into acetone, embedded in epoxy resin $\left(\mathrm{PELCO}^{\circledR}\right.$ Eponate $12 \mathrm{Kit}$, Ted Pella Inc.) and sectioned using an ultramicrotome (U1tracut, Reichert-Jung). Ultrathin sections mounted on copper grids were stained with uranyl acetate and lead citrate and examined with a transmission electron (Zeiss EM10) microscope.

Polymerase chain reaction (PCR). Template DNA was extracted from approximately $35 \mathrm{mg}$ of ethanol-fixed samples (Qiagen DNeasy kits) into sterile deionized, distilled water $\left(\mathrm{ddH}_{2} 0\right)$. The primers used for PCR are listed in Table 1. Parvicapsula minibicornis SSU rDNA was amplified as

This paper was presented at the 6th International Symposium on Fish Parasites in Bloemfontein, South Africa, 22-26 September 2003. 
Table 1. Oligonucleotide primers used to amplify segments of the small-subunit ribosomal RNA gene by polymerase chain reaction.

\begin{tabular}{|l|l|c|l|}
\hline \multicolumn{1}{|c|}{ Primers } & \multicolumn{1}{|c|}{ 5'-3' sequence } & Location $^{2}$ & \multicolumn{1}{|c|}{ Reference } \\
\hline 18e & ctg gtt gat cct gcc agt & - & Hillis and Dixon 1991 \\
18g & ggt agt agc gac ggg cgg tgt g & - & Hillis and Dixon 1991 \\
Parvi1f & gag gta aca caa gga gcc & 167 & Kent et al. 2000 \\
Parvi2r & cct caa tct taa ttc ttc aga & 1186 & Kent et al. 2000 \\
So1f & gca gtc aca cca gca tcg & 148 & Kent et al. 1998 \\
So2r & caa ttg aaa cgt cgt cgg & 297 & Kent et al. 1998 \\
Myxgp2f & wtg gat aac cgt ggg aaa & 113 & Kent et al. 1998 \\
Sm2r & ctt ggt tag cat cta cct & 325 & Kent et al. 1998 \\
So9r & caa aac gga aac caa cat cc & 996 & Present study \\
So10f & ttg gga gtg acg tac gga tt & 910 & Present study \\
\hline
\end{tabular}

${ }^{1}$ Parvi: Parvicapsula minibicornis, So: Sphaerospora oncorhynchi, Myxgp: myxozoa general primer, Sm: Sphaerospora molnari. ${ }^{2}$ Locations are relative to respective 18S rDNA sequences available in GenBank: P. minibicornis, accession number AF201375 and Sphaerospora oncorhynchi, accession number AF201373.

described earlier (Kent et al. 2000, St.-Hilaire et al. 2002). For amplification of Sphaerospora oncorhynchi SSU rDNA, 1.25 $\mathrm{U}$ Platinum Taq polymerase (Invitrogen), $1.5 \mathrm{mM} \mathrm{MgCl}_{2}$ (Invitrogen), $1 \times$ PCR buffer (Invitrogen), $0.5 \mu \mathrm{M}$ of each primer, $0.2 \mathrm{mM}$ of each $\mathrm{dNTP}$, and $1.5 \mu \mathrm{DNA}$ template $(\leq 20$ $\mu \mathrm{g} / \mathrm{ml})$ in $\mathrm{ddH}_{2} \mathrm{O}$ were used in reaction volumes of $25 \mu \mathrm{l}$. Reactions were conducted in a PTC-200 thermocycler (MJ Research). The amplification protocol was $95^{\circ} \mathrm{C}$ for $3 \mathrm{~min}, 40$ cycles of $94^{\circ} \mathrm{C}$ for $45 \mathrm{~s}, 50-55^{\circ} \mathrm{C}$ for $45 \mathrm{~s}$ and $72^{\circ} \mathrm{C}$ for $45 \mathrm{~s}$ followed by $72^{\circ} \mathrm{C}$ for $10 \mathrm{~min}$. PCR amplification products were electrophoretically resolved and visualised with ethidium bromide in $1.5 \%$ agarose gels by UV-transillumination.

Cloning and sequencing of PCR products. PCR products from the amplification of DNA from infected tissue (primers So1f and So2r, Myxgp2f and Sm2r) were directly sequenced. In addition, the product amplified using primers $18 \mathrm{e}$ and $18 \mathrm{~g}$ was purified (QIAquick PCR Purification Kit, Qiagen) and cloned following manufacturer's protocols (TOPO TA Clone kit, Invitrogen Canada Inc.). Clones were screened using PCR (primers Solf and So2r) and positive inserts amplified using two overlapping primer pairs (M13f and So9r, So10f and 18g). Primer M13f recognised a plasmid sequence adjacent to the cloning site and was provided by the manufacturer. Purified PCR products were sequenced in a BigDye Terminator Cycle Sequencing Ready reaction (Applied Biosystems). Each $20 \mu \mathrm{l}$ reaction contained 10-40 ng of PCR product, 3.2 pmols of each primer, $4 \mu 1$ BigDye Terminator RR Mix, and $4 \mu 12.5 \times$ BDT buffer (200 mM Tris, $\mathrm{pH} 8.6,5 \mathrm{mM} \mathrm{MgCl}_{2}$ ) in $\mathrm{ddH}_{2} \mathrm{O}$. Reactions consisted of 25 cycles of $96^{\circ} \mathrm{C}$ for $10 \mathrm{~s}, 50^{\circ} \mathrm{C}$ for $5 \mathrm{~s}$ and $60^{\circ} \mathrm{C}$ for $4 \mathrm{~min}$. Extension products were purified (CentriSep chromatography, Princeton Separations, Inc.), rehydrated with $\mathrm{ddH}_{2} \mathrm{O}$ and bidirectionally sequenced (ABI Prism 377, Applied Biosystems).

Individual sequences and contigs assembled using Sequencher 4.1.4 (Gene Codes Corporation) were BLAST analysed (http://www.ncbi.nlm.nih.gov/BLAST/) and then aligned (MultAlin, Corpet 1988) with those from other Sphaerospora spp. and phylogenetically related myxozoans as illustrated by Kent et al. (2001). Phylogenetic relationships between our sequences and related published sequences were estimated using neighbour-joining (NJ) and maximum parsimony algorithms in MEGA 2.1 (Kumar et al. 2001). Kimura 2-parameter analysis was used for the $\mathrm{NJ}$ analysis and bootstrap values, calculated as percentages over 1000 replicates, provided an estimate of confidence in branch nodes. Sequences from the following organisms (GenBank accession number) were used in the comparisons: Sphaerospora oncorhynchi (AF201373), Sphaerospora molnari (AF378345), Myxidium truttae (AF201374), Myxidium lieberkuehni (X76639), Myxidium sp. (U13829), Kudoa thyrsites (AF031412) and Parvicapsula minibicornis (AF201375).

Digoxygenin (DIG)-labelled probe and in situ hybridisation (ISH). Products from Solf and Solr primed PCRs were purified and $100 \mathrm{ng}$ used as template DNA to prepare a DIGlabelled probe following the manufacturer's protocol (Roche PCR DIG Probe Synthesis Kit). The PCR protocol described above was followed but with an annealing temperature of $53^{\circ} \mathrm{C}$. Labelled products from several reactions were pooled, purified, quantified (Genequant) and stored at $-20^{\circ} \mathrm{C}$. Tissue sections mounted on AAS slides were deparaffinised in xylene and baked overnight at $60^{\circ} \mathrm{C}$. The probe was used at a concentration of $0.3 \mathrm{ng} / \mu 1$ and incubated at $40 \mathrm{ng}$ per section following the method of Jones et al. (2003). Stained sections were examined with a compound microscope $(400 \times)$. Micrographs were obtained with a Nikon Coolpix 995 digital imaging system mounted on a Leitz Dialux 22 compound microscope.

\section{RESULTS}

The myxosporean-like parasite (CKX) was present in all three of the initial diagnostic samples from the Quatse River, in one sample from the Waukwaas River but not in any from each of the Marble and Washlawis Rivers in British Columbia. Subsequent sampling in British Columbia and Washington revealed CKX in stained histological preparations from $78.9 \%$ of spawning coho from four of five streams in Northern Vancouver Island, British Columbia (BC) and the Olympic Peninsula, Washington (Table 2). In addition, the parasite occurred in all nine kidney samples collected from Cluxewe River (BC) coho but not in any of the seven from the Wenatchee River (Washington) or in any of the 11 from the Methow River (Washington). 
Table 2. Histological and polymerase chain reaction (PCR) analyses of kidney from adult coho salmon collected in streams in British Columbia (BC) and Washington (WA).

\begin{tabular}{|l|c|c|c|c|c|}
\hline \multirow{2}{*}{\multicolumn{1}{c|}{ Location }} & \multicolumn{3}{|c|}{ Histology } & \multicolumn{2}{c|}{ PCR Primers $^{2}$} \\
\cline { 2 - 6 } & CKX & Myxidium & Sphaerospora & So1f/So2r & Parvi1f/Parvi2r \\
\hline Quatse River, BC & $6 / 8^{3}$ & $1 / 8$ & $0 / 8$ & $8 / 8$ & $0 / 8$ \\
Marble River, BC & $0 / 3$ & n.d. & n.d. & $0 / 3$ & $0 / 3$ \\
Waukwaas River, BC & $7 / 7$ & $1 / 8$ & $0 / 8$ & $7 / 7$ & $0 / 7$ \\
Quinault River, WA & $10 / 10$ & $3 / 10$ & $0 / 10$ & $10 / 10$ & $2 / 10$ \\
Sooes River, WA & $7 / 10$ & $3 / 10$ & $1 / 10$ & $9 / 10$ & $0 / 10$ \\
\hline
\end{tabular}

${ }^{1}$ CKX, unknown coho kidney parasite; Myxidium, mature spores in kidney tubule; Sphaerospora, mature spore in kidney tubule. Gram or modified Pappenheim-stained sections. ${ }^{2}$ See Table 1 for primer sequence and specificity. So1f/So1r: Sphaerospora oncorhynchi - positive indicates production of a 150bp band; Parvilf/Parvi2r: Parvicapsula minibicornis - positive indicates production of a 1019bp band. ${ }^{3}$ Number positive / number examined.

In stained histological sections, CKX occurred as round to elongate cells within renal tubule epithelial cells, tubule lumina and occasionally, the renal interstitium (Figs. 1, 2). The distribution of the histological changes was focal within the posterior kidney. Infected epithelial cells were hypertrophic and the adjacent lumen was often stenotic. The organism was not evident in liver, spleen, heart and gill from five Quatse River coho. From one to as many as 16 secondary cells were observed within primary intraepithelial cells (Fig. 3). Secondary cells were round to ovate and their nuclei stained prominently with Gram (Fig. 3). As the number of secondary cells increased they became peripherally distributed within the primary cell and stained more intensely (Figs. 1,2). Primary cells containing numerous intensely-stained secondary cells were frequently observed within the lumen of tubules (Fig. 1) and occasionally, protruding from the epithelium into the lumen (Fig. 2) and among interstitial cells adjacent to affected tubules. These primary cells were weakly PAS-positive. Inflammatory cells were rarely associated with affected tubules or interstitial stages.

In addition, spores of a Myxidium sp. (Fig. 4) and a Sphaerospora sp. were observed in the renal tubule lumina of $22.2 \%$ and $2.7 \%$ respectively, of coho salmon infected with CKX (Table 2).

Transmission electron microscopy (TEM) revealed that infected tubule epithelial cells contained from one to several primary cells (Figs. 5, 6). The mitochondria of infected epithelial cells were distorted or absent, the cytoplasm was vacuolated, endoplasmic reticula were compressed adjacent to the primary parasitic cells and the host-cell nucleus was displaced apically with an enlarged perinuclear space (Fig. 5). The intraepithelial primary cell enveloped from one to several secondary cells (Figs. 5, 6). Membrane-bounded secondary cells occurred individually or as pairs in which one cell partially enveloped the other (Fig. 6). Secondary cells possessed a nucleus with a prominent nucleolus and several perinuclear mitochondria that were circular in profile with well-developed cristae. Structures resembling microtubules were occasionally observed adjacent to the nucleus of secondary cells (Fig. 7). Dividing stages of secondary cells were infrequently observed. The cytoplasm of secondary cells tended to be more electron-dense in intraluminal compared with intraepithelial primary cells (Fig. 8). Intraluminal primary cells also contained numerous amorphous, electron-dense structures (Figs. 5, 7) and occasionally appeared vacuolated (Fig. 8). Neither tertiary cells nor sporogony was observed by TEM.

Polymerase chain reaction (PCR) using primers Solf and So2r amplified a 150 base-pair (bp) DNA product from all 15 coho examined from two of three rivers on Vancouver Island (Table 2). This PCR also amplified DNA from all nine Cluxewe River coho, from all 10 Quinault River coho and from nine of 10 Sooes River coho. The negative sample was one of three from the latter site that were also negative by histology. Similarly, DNA was not amplified from three coho from Marble River in which CKX was not detected by histology. Parvicapsula minibicornis DNA was amplified from two of 10 coho from the Quinault River (Table 2) and not from any other sample.

Formazan staining was associated with CKX stages (intraepithelial, luminal and interstitial primary and secondary cells) following hybridisation with the $150 \mathrm{bp}$ digoxygenin-labelled probe (Fig. 2). Similar reactions were not produced following hybridisation of Kudoa thyrsites or Parvicapsula minibicornis-infected tissues from Atlantic salmon or sockeye salmon, respectively with this probe.

A consensus sequence of $141 \mathrm{bp}$ of $18 \mathrm{~S}$ rDNA amplified from three coho (2 Quatse River, 1 Cluxewe River) using primers Solf and Solr shared 91\% identity with the homologous sequence of Sphaerospora oncorhynchi. Similarly, the $166 \mathrm{bp}$ of sequence amplified from another Quatse River coho using primers Myxgp2f and Sm2r was most like that of $S$. oncorhynchi with $91 \%$ identity. A fragment of $18 \mathrm{~S}$ rDNA amplified from a cloned segment (primers M13f and So9r), originally obtained from a fifth coho (Waukwaas River, B.C.), shared $95 \%$ identity with the homologous $S$. oncorhynchi sequence over $944 \mathrm{bp}$. The cloned CKX sequence has been deposited in GenBank (accession number AY 525343). Phylogenetic analyses using neighbour-joining 


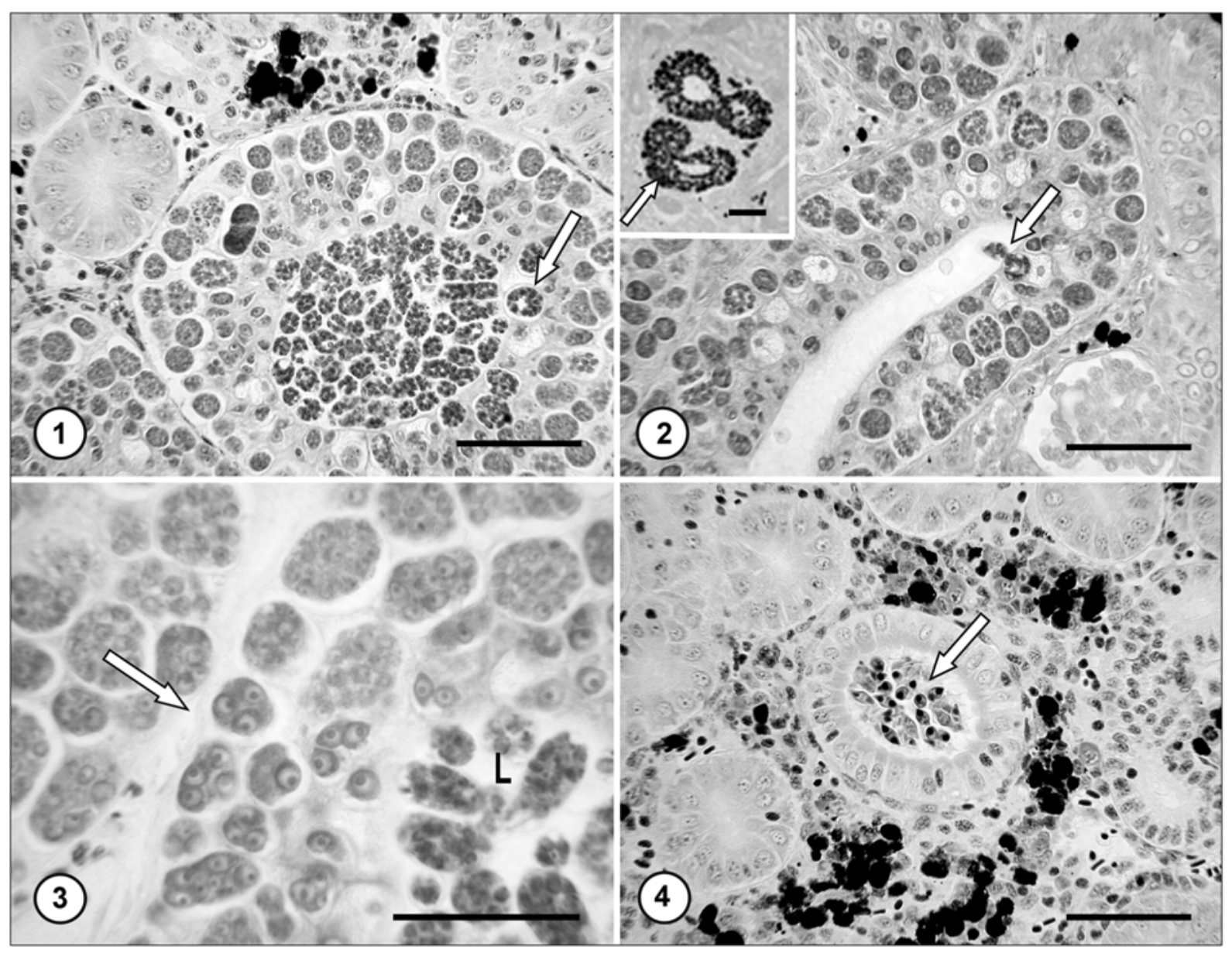

Figs. 1-4. Light micrographs of coho salmon (Oncorhynchus kisutch) kidney infected with the unknown coho kidney parasite (CKX) or with Myxidium sp. Fig. 1. Renal tubule with CKX in epithelial cells and lumen. Peripheral arrangement of intenselystained secondary cells within primary cell (arrow). Primary cells in lumen with numerous, intensely-stained secondary cells. Gram stain. Fig. 2. Primary cell containing numerous, intensely-stained secondary cells protruding from epithelium into lumen (arrow). Modified Pappenheim stain. Inset. In situ hybridisation reaction of CKX-infected renal tubules (arrow). Fig. 3. CKX within tubule epithelial cells of adjacent tubules separated by connective tissue (arrow) and in the tubule lumen (L). Primary cells contain from one to several secondary cells. Gram stain. Fig. 4. Myxidium sp. spores (arrow) in tubule lumen of CKX-infected coho. Gram stain. Scale bars: Figs. 1, 2, $4=50 \mu \mathrm{m}$; Fig. 2, inset $=20 \mu \mathrm{m}$; Fig. $3=30 \mu \mathrm{m}$.

(NJ) (Fig. 9) and maximum parsimony (MP) (not shown) methods were conducted on homologous nucleotide sequences obtained from GenBank and on the cloned sequence obtained from the present study. The topologies of unrooted phylograms obtained using both methods were similar and indicated that the CKX and $S$. oncorhynchi grouping was most closely related to $M$. lieberkuehni.

\section{DISCUSSION}

Light and electron microscopic examination confirmed that CKX possessed some features typical of Myxosporea: cell-within-cell organisation and glycogen within secondary cells (Lom et al. 1982). Structures similar to the microtubule bundles observed in M. lieberkuehni by Lom and Puytorac (1965) were occasion- ally seen in CKX, however, their pleomorphic morphology was not completely consistent with microtubules. Generic and specific identifications within the class Myxosporea however are principally based on spore morphology. Extrasporogonic stages tend to be morphologically similar, limiting their taxonomic value. Morphological features suggested that the CKX organisms were extrasporogonic myxosporean stages, and thus provided little information on their specific identity. Similarly, the focal pattern of CKX development without evident inflammation was not similar to that described previously for myxosporeans in the kidney of North American salmonids. Histological observations suggested that CKX developed within renal tubule epithelial cells from primary cells containing one secondary cell to those containing 16 or more secondary cells. The latter stages 


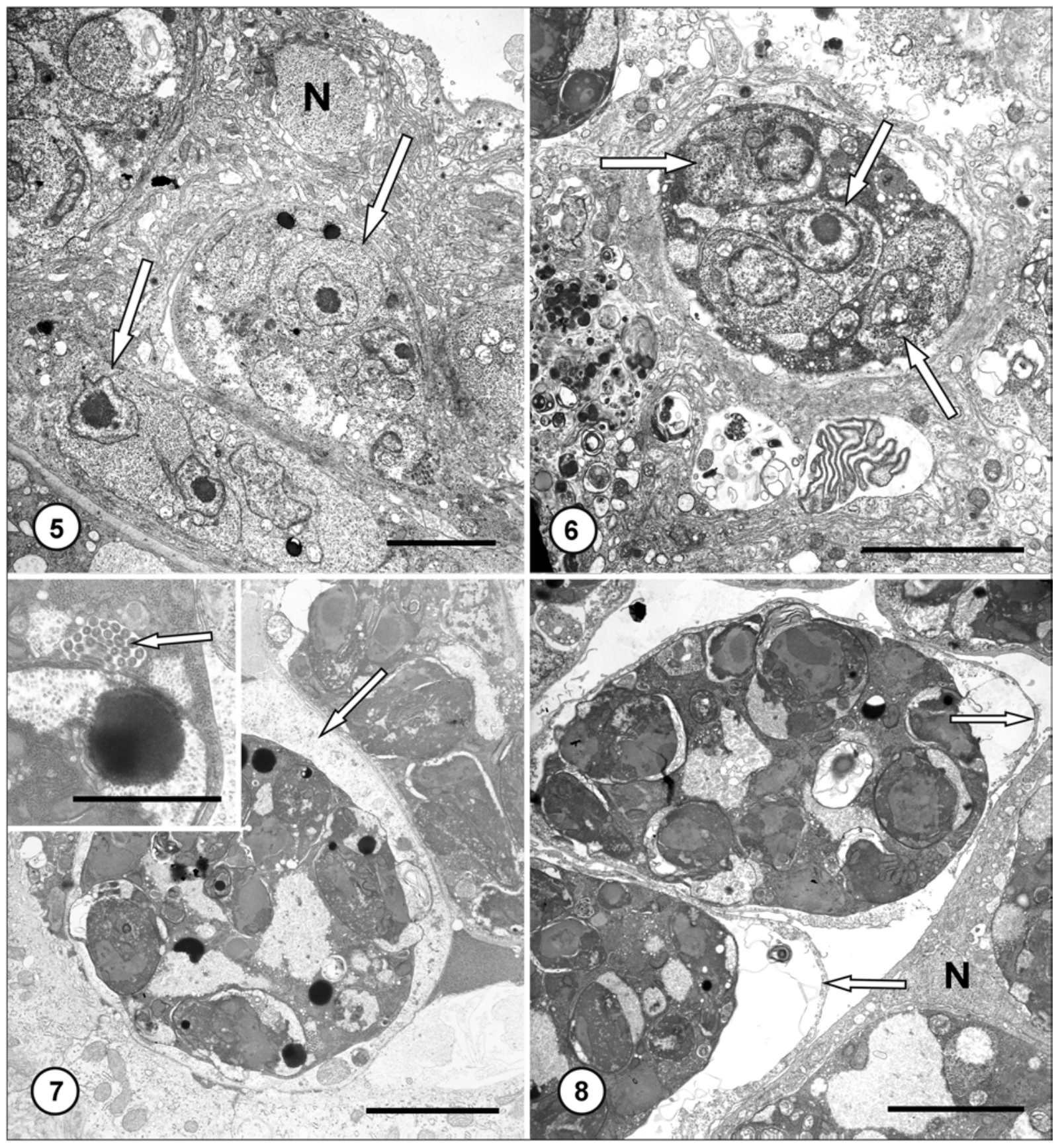

Figs. 5-8. Transmission electron micrographs of coho salmon (Oncorhynchus kisutch) kidney infected with the unknown coho kidney parasite. Fig. 5. Tubule epithelial cell containing two primary cells (arrows), each containing secondary cells. Host cell cytoplasm is vacuolated and the nucleus $(\mathrm{N})$ is displaced apically. Fig. 6. Electron-dense primary cell containing single or paired secondary cells (arrows) in which one cell partially envelops the other. Degeneration of host cytoplasm and organelles is evident. Fig. 7. Intact intraluminal primary cell (arrow) containing electron-dense secondary cells. Inset. Higher magnification of Fig. 7 showing transverse section through a bundle of microtubule-like structures adjacent to a secondary cell (arrow). Fig. 8. Vacuolated intraluminal primary cells (arrows) containing electron-dense secondary cells. Nucleus of infected epithelial cell (N) is displaced apically. Scale bars: Figs. $5-8=5 \mu \mathrm{m}$; Fig. 7, inset $=1 \mu \mathrm{m}$.

stained more intensely in histological preparations, were more electron-dense and appeared to pass into the tubule lumen. The initial infective stage was not identified although subsequent primary cells may each have derived from a secondary cell pair in which one cell par- tially enveloped the other. Similarly, sporogonic stages were not observed and some intraluminal primary cells appeared degenerate, suggesting that development was abortive. Infection with CKX was unlike that of Tetracapsula bryosalmonae which causes proliferative kid- 


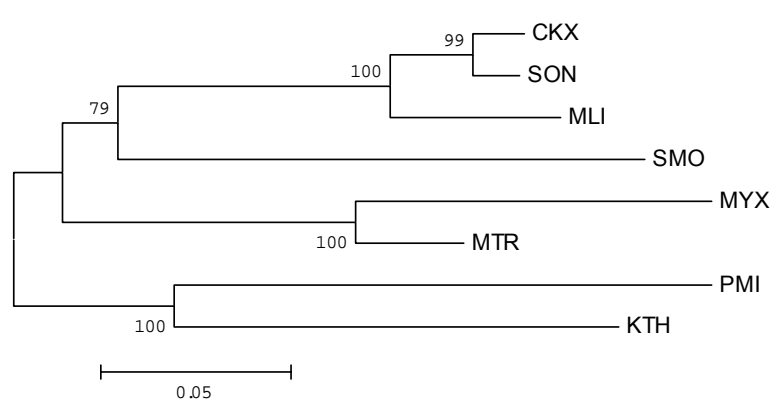

Fig. 9. Unrooted neighbour-joining phylogram showing relationships among 18S rDNA sequences of the unidentified coho salmon kidney parasite (CKX) and other myxosporeans. Comparisons were based on approximately $944 \mathrm{bp}$ of $18 \mathrm{~S}$ rDNA sequences. Numbers at nodes are bootstrap confidence levels based on 1000 resamplings. The divergence scale represents the proportion of sites that differ among sequences. Sequences compared included: SON - Sphaerospora oncorhynchi, MLI - Myxidium lieberkuehni, SMO - Sphaerospora molnari, MYX - Myxidium sp., MTR - Myxidium truttae, PMI - Parvicapsula minibicornis, KTH - Kudoa thyrsites.

ney disease (PKD), a severe, disseminated inflammation of the salmonid kidney (Hedrick et al. 1993). The development of other myxosporean species infecting the kidney of western North American Oncorhynchus spp. (Myxidium salvelini, M. minteri, Chloromyxum majori, Sphaerospora oncorhynchi, Parvicapsula minibicornis) occurs entirely within glomeruli, renal tubules, collecting ducts or the urinary bladder. In contrast, several histozoic, proliferative renal myxosporidioses have been reported from non-salmonid species, including those caused by Sphaerospora renicola in common carp (Cyprinus carpio) (Lom et al. 1982), Myxidium lieberkuehni in northern pike (Esox lucius) (Lom et al. 1989) and Hoferellus cyprini in C. carpio (Molnár and Kovács-Gayer 1986). CKX is strikingly similar to the extrasporogonic developmental stages of $S$. renicola (Lom and Dyková 1985).

Polymerase chain reaction (PCR) using $S$. oncorhynchi-specific primers amplified DNA from all specimens with histological criteria of CKX infection and from some that did not. The latter were undoubtedly light infections undetectable by histology. Sequencing the $18 \mathrm{~S}$ ribosomal gene confirmed the myxosporean affinities of CKX and demonstrated its similarity to $S$. oncorhynchi. Sphaerospora oncorhynchi was described originally from sockeye salmon $(O$. nerka) in British Columbia (Kent et al. 1993), suggesting that it is a sister taxon of CKX. The 18S rDNA sequence of CKX was found also to be similar to Myxidium lieberkuehni, consistent with the phylogenetic relationships among some Myxidium and Sphaerospora species hypothesised by Kent et al. (2001). However, given that available SSU sequence data indicate these genera to be paraphyletic (Kent et al. 2001), the present analysis serves mainly to confirm the close relationship of CKX to both $S$. oncorhynchi and M. lieberkuehni. The similarities of
CKX 18S rDNA sequences to those of Sphaerospora and Myxidium suggest that CKX might be a previously unrecognised proliferative stage of $M$. salvelini, $M$. minteri or an undescribed species of Sphaerospora or Myxidium.

In situ hybridisation using a DIG-labelled probe was used on tissue sections to identify the source and location of DNA used for PCR and sequencing studies. The pattern of CKX staining obtained by ISH was identical to that of traditional histological staining. Under conditions of relatively low stringency, hybridisation may occur between the probe and DNA from $S$. oncorhynchi or related organisms including $M$. lieberkuehni. Thus, while more work is required to derive a probe unique for the CKX organism, the probe failed to hybridize with uninfected kidney and with some other Myxosporea of salmon in western North America. Similarly, the low sequence identity between the CKX probe and the homologous $T$. bryosalmonae sequence indicates the low probability of cross-hybridisation with the latter organism.

Our inability to specifically identify CKX notwithstanding, a particularly noteworthy aspect of this study was the coincident first detection of CKX infections in coho salmon from British Columbia and Washington. It is possible that $\mathrm{CKX}$ is a species of myxosporean previously unrecognised despite extensive parasitological surveys of salmonids from Oregon to British Columbia. An alternative hypothesis is that CKX is a known species displaying an unusual pattern of development because of the influence of unknown factors. The recent finding of CKX in spawning pink salmon Oncorhynchus gorbuscha (Walbaum) in British Columbia (Jones, unpublished observations) suggested that infection of an inappropriate host does not explain the histozoic development. Most coho in this study were not examined for bacterial infections and a relationship between the original diagnosis of Aeromonas salmonicida and CKX infections in those coho is unknown. Hamilton (1980) suggested that mixed infections with Sphaerospora sp. and A. salmonicida increased the susceptibility of goldfish to subsequent infection. Spawning and post-spawn senescence among Oncorhynchus spp. is associated with systemic degeneration, including immune incompetence (Schreck 1996). We suggest that the histozoic development of CKX is a consequence of this physiological degeneration. Specifically, we hypothesise that immune incompetence among spawning and post-spawn salmon provided a permissive environment for histozoic development of a species that, in the competent host, undergoes a strict coelozoic cycle of development. The unidentified Myxidium or Sphaerospora spores observed in CKX-infected coho may be remnants of this earlier cycle. The degenerate appearance of intraluminal CKX stages with no evidence of sporogony indicated that the developmental cycle was not presporogonic and was probably abortive. Whether 
extrasporogonic development among other myxosporean species necessarily precedes or is required for sporulation to occur is not well understood (Lom and Dyková 1995). Sphaerospora renicola undergoes an increased frequency of abortive extrasporogonic development coincident with colder months (Grupcheva et al. 1985), suggesting a role for temperature in this process. The findings of CKX among two species of spawning Pacific salmon indicated that the parasite is not host specific and that conditions promoting the extrasporogonic pattern of development are widespread in spawn- ing fish, consistent with the senescence hypothesis. Understanding the factors that regulate potentially pathogenic extrasporogonic development among otherwise non-histozoic Myxosporea will be a valuable field of research. Furthermore, the fishery management implications of understanding senescence-associated disease in Pacific salmon have not gone unnoticed.

Acknowledgements. This study was funded by Fisheries and Oceans Canada. The authors are grateful to Dr. Sonia Mumford, US Fish and Wildlife Service for providing salmon samples from Washington.

\section{REFERENCES}

CORPET F. 1988: Multiple sequence alignment with hierarchical clustering. Nucl. Acids Res. 16: 10881-10890.

GRUPCHEVA G., DYKOVÁ I., LOM J. 1985: Seasonal fluctuation in the prevalence of Sphaerospora renicola and myxosporean bloodstream stages in carp fingerlings in Bulgaria. Folia Parasitol. 32: 193-203.

HAMILTON R.C. 1980: Ultrastructure of a Sphaerospora sp. (Myxosporida) in goldfish kidneys. Micron 11: 499-500.

HEDRICK R.P., MacCONNELL E., De KINKELIN P. 1993: Proliferative kidney disease of salmonid fish. Annu. Rev. Fish Dis. 3: 277-290.

HILLIS D.M., DIXON M.T. 1991: Ribosomal DNA: molecular evolution and phylogenetic inference. Q. Rev. Biol. 66: 411-453.

HUMASON G.L. 1972: Animal Tissue Techniques. W.H. Freeman, San Francisco, 641 pp.

JONES S.R.M., GOH B., PROSPERI-PORTA G. 2003: Duration and method of fixation affects the sensitivity of a digoxygenin-labelled DNA probe in detecting Kudoa thyrsites in Atlantic salmon skeletal muscle. Aquaculture 220: $157-164$.

KENT M.L., ANDREE K.B., BARTHOLOMEW J.L., ElMATBOULI M., DESSER S.S., DEVLIN R.H., FEIST S.W., HEDRICK R.P., HOFFMANN R.W., KHATTRA J., HALLETT S.L., LESTER R.J.G., LONGSHAW M., PALENZUELA O., SIDDALL M.E., XIAO C. 2001: Recent advances in our knowledge of the Myxozoa. J. Eukaryot. Microbiol. 48: 395-413.

KENT M.L., KHATTRA J., HEDRICK R.P., DEVLIN R.H. 2000: Tetracapsula renicola n. sp. (Myxozoa: Saccosporidae); the PKX myxozoan - the cause of proliferative kidney disease of salmonid fishes. J. Parasitol. 86: 103111.

KENT M.L., KHATTRA J., HERVIO D.M.L., DEVLIN R.H. 1998: Ribosomal DNA sequence analysis of isolates of the PKX myxosporean and their relationship to members of the genus Sphaerospora. J. Aquat. Anim. Health 10: 1221.

KENT M.L., WHITAKER D.J., MARGOLIS L. 1993: Sphaerospora oncorhynchi n. sp. (Myxosporea: Sphaero- sporidae) from the kidney of sockeye salmon (Oncorhynchus nerka) in British Columbia and its possible relationship to the myxosporean causing proliferative kidney disease in salmonid fishes. Can. J. Zool. 71: 2425-2430.

KUMAR S., TAMURA K., JAKOBSEN I.B., NEI M. 2001: MEGA2: Molecular Evolutionary Genetics Analysis software, Arizona State University, Tempe, Arizona, USA.

LOM J., de PUYTORAC P. 1965: Studies on the myxosporidian ultrastructure and polar capsule development. Protistologica 1: 53-65.

LOM J., DYKOVÁ I. 1985: Hoferellus cyprini Doflein, 1898 from carp kidney: a well established myxosporean species or a sequence in the developmental cycle of Sphaerospora renicola Dyková and Lom, 1982? Protistologica 21: 195206.

LOM J., DYKOVÁ I. 1995: Myxosporea (Phylum Myxozoa). In: P.T.K. Woo (Ed.), Fish Diseases and Disorders. Vol. 1. Protozoan and Metazoan Infections. CAB International, Wallingford, pp. 97-148.

LOM J., DYKOVÁ I., FEIST S. 1989: Myxosporea-induced xenoma formation in pike (Esox lucius L.) renal corpuscles associated with Myxidium lieberkuehni infection. Eur. J. Protistol. 24: 271-280.

LOM J., DYKOVÁ I., LHOTÁKOVÁ S. 1982: Fine structure of Sphaerospora renicola Dyková and Lom, 1982 a myxosporean from carp kidney and comments on the origin of pansporoblasts. Protistologica 18: 489-502.

MOLNÁR K., KOVÁCS-GAYER É. 1986: Observations on the intracellular and coelozoic developmental stages of Hoferellus cyprini (Doflein, 1898) (Myxosporea, Myxozoa). Parasitol. Hung. 19: 27-30.

SCHRECK C.B. 1996: Immunomodulation: endogenous factors. In: G. Iwama and T. Nakanishi (Eds.), The Fish Immune System: Organism, Pathogen and Environment. Academic Press, London, pp. 311-337.

St.-HILAIRE S., BOICHUK M., BARNES D., HIGGINS M., DEVLIN R., WITHLER R., KHATTRA J., JONES S., KIESER D. 2002: Epizootiology of Parvicapsula minibicornis in Fraser River sockeye salmon, Oncorhynchus nerka (Walbaum). J. Fish Dis. 25: 107-120. 